\title{
IMPLEMENTASI KONSEP HOMO ISLAMICUS MONZER KAHF DALAM ENTERPRENEURSHIP KIAI MAHMUD ALI ZAIN
}

\author{
Nurul Huda \\ Universitas Nurul Jadid \\ Email:_enha300681@gmail.com
}

\begin{abstract}
Islam as a religion that emphasizes a balance of life between the world and the hereafter, of course, welfare as the goal of economic activity also includes these two lives. In homo islamicus Monzer Kahf, Islamic economic activity does not prioritize satisfaction, but prioritizes interests in the comfort of others and does not harm each other in order to create a balanced society in which only hopes to get the pleasure of Allah SWT. Using the literature of Kahf's works, this article seeks to parse the implementation of homo Islamicus values such as rationality, balance, the concept of property ownership, and economic ethics in real life. The results of this study found the suitability of Kiai Mahmud Ali's entrepreneurship in establishing sharia-based business entities with the homo islamicus Kahf concept, one of which is Bait al-Mal Wa alTamwil (BMT). Kiai Mahmud's Entrepreneurship practice illustrates the persistence in holding the homo Islamicus belief that God is the owner of the universe and the supreme lawmaker, while humans only endeavor with the legitimacy of hard work as a virtue.
\end{abstract}

Keywords: Islamic man, Enterpreunership, and Ekonomi Syari'ah.

\begin{abstract}
Abstrak
Islam sebagai agama yang menghendaki keseimbangan hidup antara dunia dan akhirat, tentu kesejahteraan sebagai tujuan kegiatan ekonomi juga meliputi dua kehidupan tersebut. Dalam homo islamicus Monzer Kahf, kegiatan ekonomi Islam tidak mengutamakan kepuasan, melainkan mendahulukan kepentingan dalam kenyamanan orang lain dan tidak saling merugikan agar menciptakan masyarakat seimbang yang di dalamnya hanya berharap mendapatkan ridla Allah SWT. Dengan menggunakan literatur karya-karya Kahf, artikel ini berusaha mengurai implemetasi nilai-nilai homo islamicus seperti rasionalitas, seimbang, konsepk kepemilikan barang, dan etika ekonomi dalam kehidupan nyata. Hasil penelitian ini menemukan kesesuaian enterprenuership Kiai Mahmud Ali dalam mendirikan badan usahabadan usaha yang berbasis syariah dengan konsep homo islamicus Kahf, salah satunya berupa Bait al-Mal Wa al-Tamwil (BMT). Praktik Enterpreneurship Kiai Mahmud menggambarkan keteguhan memegang keyakinan homo islamicus bahwa Tuhan merupakan pemilik alam semesta dan pembuat hukum tertinggi, sementara manusia hanya berikhtiar dengan legitimasi kerja keras sebagai sebuah kebajikan.
\end{abstract}

Kata Kunci: Homo Islamicus, Enterpreunership, dan Ekonomi Syari'ah. 


\section{PENDAHULUAN}

Enterpreneurship merupakan istilah yang semakin ngetren dan dianggap sebagai solusi untuk meningkatkan perekonomian suatu negara. Islam sebagai agama yang diyakini oleh pemeluknya memiliki nilai-nilai universal, mulai didialogkan untuk menjawab persoalan-persoalan yang berhubungan dengan ekonomi, seperti krisis ekonomi, rendahnya daya beli, rendahnya pendapatan dan lain sebagainya. Trend ekonomi Islam semakin memiliki ruang di saat ideologi ekonomi liberalis dan sosialis dinilai tidak mampu meningkatkan kesejahteraan tanpa mengorbankan orang lain. Dengan perpegang pada prinsip rasionalitas dalam mengonsumi, kehalalan dalam bertransaksi, kepedulian terhadap sesama, keseimbangan dalam berusaha, dan tawakal setelah berusaha merupakan seperangkat nilai yang yang diyakini dapat membangun semangat enterpreneurship yang islami atau yang oleh Monzer Kahf disebut homo islamicus atau Islamic man.

Istilah homo islamicus menurut Kahf merupakan manusia yang taat terhadap syariat dengan menjadikan kegiatan ekonomi tidak semata-mata untuk memperoleh keuntungan (rational ekonomic man), tetapi juga mendapatkan ridla Allah SWT (Santoso, 2016). Enterpreneurship model ini tentu kontras dengan beberapa teori neo klasik yang menitik beratkan kalkulasi matematis untuk menentukan nilai optimal atau dalam teori Kirzerian disebut sebagai entrepreneur yang hanya menyoroti tentang kinerja manusia, keuletanya, keseriusanya, dan kesungguhanya (Nurrokhman, 2021). Sementara Homo islamicus lebih dari itu, yakni manusia yang memiliki kepedulian yang tinggi terhadap orang lain dengan bershadaqah, infaq, dan zakat (Santoso, 2016).

Istilah enterpreneurship secara operasional didefiniskan sebagai seseorang yang menciptakan sebuah usaha atau bisnis yang dihadapkan dengan resiko dan ketidakpastian untuk memperoleh keuntungan dan mengembangkan bisnis dengan cara mengenali kesempatan dan memanfaatkan sumber daya yang diperlukan (Triningtyas, 2016). Sementara di dalam agama Islam, enterpreneurship diimplemetasikan dengan cara yang baik sesuai syariat Islam yang sudah termaktub dalam al-Qur'an dan sunnah. Hal ini sesuai dengan hasil penelitiannya Havis Arafik bahwa manusia yang hendak dibentuk oleh Islam adalah homo islamicus (enterpreuner yang islami) atau dalam bahasa al-Qur'an ibad al-rahman sebagaimana yang terdapat dalam QS. Alfurqaan, 25:63 (Aravik, 2017). Homo islamicus dalam hal ini merupakan manusia kompleks yang tidak hanya sebagai human ekonomicus, tetapi juga human sosialis bahkan human religius (homo islamicus). Jika Ibad al-rahman merupakan padanan kata Islamic man, maka enterpreneurship versi Islam bisa disederhanakan sebagai manusia yang mengutamakan kesejahteraan sosial sebagai tujuan untuk mendapatkan ridlo Allah SWT (Kholis, 2015).

Homo islamicus memiliki dimensi spiritual-transendental. Sebuah enterpreneurship yang perilakunya tidak akan mementingkan diri sendiri dengan mengorbankan kepentingan sosial atau perilaku yang bertentangan dengan aturan Allah. Homo islamicus di sini adalah orang yang mempercayai bahwa semua adalah kehendak dan kuasa Allah, suksesnya usaha adalah dari Allah, tidak matrealistik karena harta yang dia miliki sebenarnya milik Allah sehingga di setiap harta ada hak orang lain, suka berbuat kebajikan berbagi kepada yang membutuhkan dan rela memberikan atau mengorbankan kesenangannya untuk orang lain (Imtinan, 2021). Motivasinya tidak hanya untuk meningkatkan keuntungan sendiri tetapi juga orang lain dengan berharap mendapatkan ganjaran kesuksesan di akhirat atau bernilai pahala (Furqani, 2011). Dengan kata lain, enterpreneurship yang islami secara sadar ditargetkan untuk mencapai kebahagiaan di dunia ini dan akhirat. Hal ini yang membedakan enterpreneurship dalam ekonomi Islam dan ekonomi sekuler. Jika ditarik dalam konteks yang lebih luas ilmu ekonomi Islam memiliki kekhasan yang tidak akan 
membatasi pandangan manusia pada keberadaannya di dunia ini tanpa memikirkan akhirat.

Ekonomi Islam merupakan ilmu pengetahuan sosial yang mempelajari masalah-masalah ekonomi masyarakat yang diilhami oleh nilai-nilai Islam (Fauzia, 2014). Ekonomi Islam sebagai disiplin ilmu baru yang secara resmi muncul pada tahun 1976 ketika diselenggarakan konferensi internasional ekonomi Islam pertama di Mekkah, memiliki pengertian khusus tentang perilaku pelaku ekonomi yang harus menerapkan prinsip / teori dalam kehidupan praktis. Para pelaku ekonomi Islam disebut sebagai Homo islamicus yang dibekali dengan asumsi-asumsi Islam dalam perilaku ekonominya (Furqani, 2011). Kemudian istilah homo islamicus secara detail diperkenalkan Monzer Kahf, sebagai enteperprenuer yang bertujuan untuk memperoleh keuntungan dan membantu meningkatkan kesejahteraan masyarakat melalui zakat, infaq, dan shadaqah.

Prinsip-prinsip seorang homo islamicus sebagaimana diperkenalkan Kahf, nampak dalam pribadi Kiai Mahmud Ali Zain yang telah banyak menginisiasi berdirinya banyak badan usaha islami atau berbasis syariah di Pesantren Sidogiri, diantarana Koperasi Pondok Pesantren (Kopontren), Bait al-Mal wa al-Tamwil (BMT) Maslahah, dan BMT Usaha Gabungan Terpadu (UGT) Sidogiri yang menyediakan layanan Koperasi Simpan Pinjam Pembiayaan Syariah (KSPPS). Ketiga Badan usaha yang sangat terkenal ini memiliki banyak anak usaha, mulai bisnis software, bisnis agro, bisnis kuliner, usaha air mineral, bisnis apartemen mahasiswa, percetakan, hingga rumah sakit.

Dari usaha-usaha tersebut, badan usaha yang didirikan Kiai Mahmud dapat dikatakan sangat sukses, setidaknya jika dilihat berdasarkan aset yang dimiliki. BMT Maslahah mampu memiliki aset hingga 538 milyar pada RAT tahun 2017 (Siregar, 2018). Sementara Kapontren lebih besar lagi karena memiliki mini-market Basmalah yang sudah berdiri dengan 126 toko dan Industri air mineral "Santri". BMT UGT Sidogiri memiliki aset terbesar yaitu 2,4 trilun pada tahun 2018 dan menargetkan 5 triliun pada tahun 2020 (Fadil, 2018). Kesuksesan ini sangat menarik, karena keseluruhan badan usaha yang didirikan berbasis pada prinsipprinsip atau aturan Islam, yang salah satunya dapat dilihat dengan mudah yakni kepedulian badan usaha-badan usaha tersebut kepada kualitas hidup orang lain dengan melahirkan program pemberdayaan masyarakat.

Sasaran program pemberdayaan masyarakat, pertama dirasakan langsung oleh santri Pesantren Sidogiri dengan murahnya pembiayaan yang harus dibayar. Dengan dana sebesar sebesar 3,4 miliar pertahun (Siregar, 2021), Pesantren Sidogiri dapat diakses semua lapisan masyarakat, termasuk masyarakat miskin. Kedua Qoryah Thayyibah yang fokus pada pemberdayaan masyarakat desa. Kegiatan ini terutama merenovasi rumah warga yang sudah tidak layak huni (Siregar, 2018). Program ini dikelola oleh Ikatan Alumni Santri Sidogiri (IASS) yang tidap tahun juga mendapatkan kucuran dan sosial dari badan usaha yang didirikan Kiai Mahmud. Bahkan program Qoryah Thayyibah ini dikomandani langsung oleh Kiai Mahmud.

Program pemberdayaan masyarakat yang dihasilkan dari badan usaha yang didirikan Kiai Mahmud menunjukkan bagaimana badan usaha tersebut sudah mengimplemntasikan prinsip-prinsip Islam atau syariah. selain itu, Kiai Mahmud sendiri sebagai pendiri dan motor penggerak layak menyandang islamic man. Dari sinilah artikel ini manjadi menarik, karena konsep homo islamicus dalam gambaran nyata nampak terealiasasi dalam pribadi Kiai Mahmud, sehingga sosoknya layak dijadikan percontohan untuk meningkatkan enterprenuership versi Islam. Selain itu, artikel ini juga menjadi sangat penting karena belum ada artikel dengan topik yang sama sebagaimana dalam penelitian ini. 


\section{LITERATUR REVIEW}

Keberhasilan badan usaha - badan usaha yang didirikan Kiai Mahmud, tentu saja menjadi perhatian banyak akademisi dan peneliti. Apalagi badan usaha tersebut didirikan oleh seorang kiai yang dibesarkan dalam pendidikan pesantren. Salah satu peneliti yang tertarik adalah $M$. Muktirrahman, M. Ridwan, dan F. Zenrif (2018) yang berjudul Peran Modal Sosial Pondok Pesantren Sidogiri dalam Mengembangkan Koperasi Jasa Keuangan Syariah yang yang meneliti BMT UGT Sidogiri dan badan usaha lainnya. Dalam penelitian ini ditemukan bahwa yang menyebabkan badan usaha yang didirikan Kiai mahmud ini sukses, karena didukung oleh modal sosial yang dimiliki Pesantren Sidogiri. Dengan jumlah santri dan utamanya alumni yang tersebar di beberapa daerah seperti Madura dan Jawa Timur, menjadi peluang atau pangsa pasar bagi usaha-usaha pesantren. Hasil penelitian ini cukup menarik karena persebaran BMT UGT Sidogiri memang banyak berada yang menjadi basis alumni Pesantren Sidogiri. Temuan ini diperkuat oleh temuan peneliti lainnya, yaitu M. Isbah, M. Falikul dengan judul How is Social Capital Converted to be Economic Capital? A Case Study from Pesantren's Socio-Economic Projects, yang juga mengupasa bagaimana modal sosial berganti menjadi bodal ekonomi.

Kemudian Peneliti yang berbeda adalah Lu'lu il Maknun (2015) dengan judul penelitian Efektivitas Promosi dan Mutasi: Studi pada Karyawan BMT Mashlahah Sidogiri. Dalam tesis ini, peneliti berusaha mengurai bagaimana kinerja karyawankaryawan BMT Maslahah, sehingga dapat menjalankan tugasnya dengan baik. Temuan dalam penelitian ini menunjukkan bahwa para karyawan BMT Maslahah dapat bertahan tidak semata-mata karena mencari berkah, lebih dari itu terdapat promosi dan mutasi yang berlaku atau dalam bahasa lainnya disebut reward dan punishment. Kemudian penlitian lainnya yang juga mengambil obyek material yang sama adalah Maktsalina Khuddami (2015) dengan judul
Pengaruh Budaya Kekeluargaan terhadap Kinerja Karyawan di BMT Maslahah Sidogiri Pasuruan. Penelitian ini juga merupakan penelitian tugas akhir atau tesis yang meneliti kinerja karyawan BMT Maslahah. Hanya saja temuannya berbeda, yaitu karyawan BMT Maslahah dapat menikmati tugasnya justru karena terdapat budaya kekeluargaan di dalamnya. Hubungan antar pekerja dipandang tidak terlalu kaku seperti hubungan kerja pada perusahan-perusahan lainnya. Budaya guyub dan penuh kekeluargaan seperti di pesantren dinilai menjadi penyebab utama peningkatan kinerja karyawan BMT Maslahah.

Beberapa penelitian tersebut membuktikan bahwa keberhasilan badan usaha yang didirikan oleh Kiai Mahmud Ali Zain telah menjadi perhatian banyak orang. Sebagian penelitian mengurai penyebab kerhasilannya, sebagiannya lagi mengurai kinerja karyawannya. Temuan-temuannya juga sangat penting, mengingat keberhasialn suatu badan usaha dapat disebabkan oleh banyak faktor. Yang absen dalam penelitianpenelitian tersebut, adalah keberhasilan badan usaha - badan usaha itu pada dasarnya tidak bisa dilepaskan dari sosok Kiai Mahmud. Dia tidak hanya sebagai pendiri, tetapi juga top leader dalam badan usaha yang dia dirikan. Disinilah penelitian ini menjadi penting, karena fokus pada topik yang belum pernah diteliti oleh peneliti lainnya, yakni enterpreneurship Kiai Mahmud.

\section{METODE PENELITIAN}

Metode penelitian ini menggunakan library research (riset kepustakaan), dimana semua data yang digunakan dalam penelitian ini bersumber dari bahan-bahan atau literaturliteratur tertulis yang berkaitan secara langsung atau tidak dengan obyek material dan formal dalam penelitian ini. Penelitian ini baik obyek material atau formal bukanlah sesuatu yang benar-benar baru. Penelitian yang menjadikan Kiai Mahmud Ali Zain dan Monzer Kahf sebagai obyek material atau sebagai obyek formal tentu sudah banyak, mengingat Kahf merupakan tokoh populer 
dalam ekonomi Islam, sementara Kiai Mahmud Ali Zain juga merupakah tokoh populer di kalangan pesantren dan dunia Islam secara umum di Indonesia. Oleh karena itu artikel ini mencoba menampilkan penelitian baru dengan menjadikan Kiai Mahmud sebagai obyek yang semangat enterpreneurnya dapat dilihat dalam prespektif homo islamicus Kahf.

Penelitian ini secara sederhana berdasarkan obyek material dan formal tersebut, berusaha mengurai enterpreneurship Kiai Mahmud melalui homo islamicus Kahf. Penggunaan konsep homo islamicus secara operasional digunakan untuk mendapatkan pemahaman tentang implementasi enterpreneurship versi Islam yang berbeda dengan enterprenuership versi sekuler yang hanya fokus untuk mendapatkan keuntungan ekonomi. Kiai Mahmud yang populer sebagai pelaku ekonomi dengan mendirikan banyak badan usaha dan penuh penghargaan bergengsi, diharapkan menjadi percontohan bagi pelaku ekonomi Islam secara khusus dan tidak menutup kemungkinan bagi pelaku ekonomi secara umum.

Sumber data dalam penelitian pustaka ini terdapat dua jenis yang digunakan, yaitu, primer dan sekunder. Sumber data primer merupakan sumber utama yang diambil langsung dari buku atau artikel karya Monzer Kahf yang relevan. Sedangkan sumber data sekunder adalah tulisan artikel, buku, dan berita yang membahas Mozer Kahf dan Kiai Mahmud yang dianggap mendukung kelengkapan data primer.

\section{KONSEP DASAR Enterpreneurship}

Sebagai istilah sudah tidak asing, enterpreneurship sebagai sebuah teori dan praktek dapat ditemukan dalam beberapa karya penelitian. Simon C. Parker (2018) dalam bukunya The Economics of Entrepreneurship. Buku itu pada dasarnya adalah monograf dari spesialis enterpreneur yang digunakan sebagai panduan kursus. Dengan merujuk pada literatur setelah 2003 (hingga pertengahan 2008) dan mencakup lebih banyak literatur sebelum 2003, konten buku ini lebih komprehensif dari buku-buku sebelumnya. Buku ini juga telah sepenuhnya ditulis ulang untuk memfasilitasi penggunaannya sebagai panduan kursus untuk program sarjana dan pascasarjana dalam kewirausahaan dalam perspektif ekonomi. Sebagai pedoman kursus, buku ini telah mengartikulasikan enterpreneurship dalam bentuk praktik, bagaimana memulai usaha hingga menjadi pengusaha yang sukses.

Banyaknya tulisan-tulisan dengan topik entrepreneurship baik dari segi teori dan praktik memicu penelitian lainnya yang mengupas bagaimana topik entrepreneurship diteliti. Karya Johan Wiklund (2011) dengan judul The future of entrepreneurship research. Entrepreneurship Theory and Practice mengulas bagaimana pada musim panas 2008, Jonkoping International Business School (JIBS) mengundang sejumlah sarjana terkemuka (dan belum melewati puncak) dalam sebuah lokakarya di mana mereka diminta untuk mempresentasikan visi mereka tentang di mana masa depan penelitian entrepreneurship. Buku dengan edisi khusus ini didasarkan pada ide-ide yang pertama kali dipresentasikan pada lokakarya 2008. Hasilnya topik entrepreneurship akan tetap menjadi perhatian utama karena pembangunan ekonomi sangat terganting pada semangat entrepreneurship.

Artikel ini membenarkan hasil lokakarya tersebut, bahwa penelitian dengan topik entrepreneurship tetap menjadi perhatian utama. Dalam penelitian ini, entrepreneurship tidak lagi diposisikan sebagai sebuh teori yang memberikan informasi kognitif kepada pembaca, melainkan beirisi tentang praktik entrepreneurship yang Islami. Dengan membaca artikel ini, pembaca diharapkan dapat memahami dan memperaktekkan bagaimana entrepreneurship yang Islami dapat diimplementasikan. 
Homo Islamicus (Islamic Man)

Konsep homo islamicus Monzer Kahf sebenarnya secara spesifik belum banyak diteliti baik sebagai obyek material maupun formal. Berbeda dengan pemikiran Kahf tentang zakat yang dinilai sebagai pemikiran terbesarnya. Penelitian Sriwahyuni (2017) dengan judul Pemikiran Ekonomi Islam Monzer Kahf membenarkan bahwa zakat merupakan gagasan besar Kahf. Dalam menciptakan keadilan ekonomi dalam suatu negara, zakat yang notabene bersumber dari al-Qur'an dan Sunnah menjadi solusi yang tepat. Dengan zakat, suatu negara dapat mencapai cita-citanya dalam menciptakan masyarakat yang adil dan makmur.

Dalam karya Haviz Aravik (2017) dengan judul Sejarah pemikiran ekonomi Islam kontemporer juga memperkuat gagasan Homo islamicus Kahf sebagai sub pemikirannya. Hal ini terlihat bahwa ulasan tentang Homo islamicus hanya dibahas sekitar setengah halaman dengan maksud untuk mendiskripsikannya semata, sebagai pelaku ekonomi yang rasional, konsisten dalam mengikuti al-Qur'an dan Sunnah, tidak materialistik, tidak konsumtif, dan peduli terhadap kesejahteraan orang lain.

Satu-satunya penelitian yang fokus pada penerapan implemetasi homo islamicus adalah penelitiannya Arlinda Nidia Corinna dan Eko Fajar Cahyono (2019). Dengan judul artikel Pola Perilaku Konsumsi Generasi Millenial terhadap Produk Fashion Perspektif Monzer Kahf: Studi Kasus Mahasiswi Universitas Airlangga, kedua penulis menjadikan homo islamicus Kahf tentang konsumsi sebagai sudut pandang atau obyek formal dalam melihat perilaku mahasiswi Universitas Airlangga dalam menggunakan produk fashion. Salah satu temuan pentingnya, penggunaan fashion di kalangan mahasiswi di Universitas Airlangga tidak menggambarkan bagaimana seharusnya prilaku konsumsi yang islami atau sesuai homo islamicus.

Penelitian ini juga merupakan penelitian yang bertujuan untuk memahami implementasi homo islamicus Kahf. Hanya saja bila penelitian sebelumnya menggunakan konsep homo islamicus untuk menilai perilaku konsumsi sebagian mahasiswa yang ternyata tidak sesuai, maka penelitian ini justru mencari satau kasus dimana homo islamicus benar-benar diimplementasikan secara utuh. Dengan menjadikan enterpreneurship Kiai Mahmud Ali Zain sebagai obyek material, homo islamicus Kahf benar-benar menjadi gugusan nilai yang implementatif dan praktis.

\section{HASIL DAN PEMBAHASAN Profil Kiai Mahmud Ali Zain}

Jiwa enterpreneurship Kiai Mahmud terbentuk bukan oleh pendidikan formal sebagaimana umumnya para ahli. Kepedulian untuk mengembangkan pesantren dan meneruskan cita-cita masyayikh terdahulu untuk menghilangkan praktek riba berupa simpan pinjam rentenir di masyarakat, membuatnya bertekad untuk mendirikan BMT UGT Sidogiri. Kiai Mahmud merupakan alumni Pesantren Sidogiri tahun 1978 yang kemudian diambil menantu oleh pengasuh pesantren tempat dia belajar (Siregar, 2018). Meski tidak pernah mengenyam pendidikan formal di bidang ekonomi, tetapi dengan ketekunan dan keyakinannya, badan usaha yang didirikannya mencapai kesuksesan seperti sekarang ini.

Kiai mahmud mendapatkan banyak penghargaan bergengsi di bidang ekonomi atas keberhasilannya mendidirikan Koperasi Pondok Pesantren (Kopontren), Bait al-Mal wa al-Tamwil (BMT) Maslahah, dan BMT Usaha Gabungan Terpadu (UGT) Sidogiri yang menyediakan layanan Koperasi Simpan Pinjam Pembiayaan Syariah (KSPPS). Presiden SBY menganugerahinya tanda kehormatan berupa Bintang Jasa Pratama sebagai tokoh yang memberikan pengabdian dan jasa luar biasa pada negara (Jempolindo, 2020). Pada masa Presiden Jokowi Kiai Mahmud juga mendapatkan penghargaan sebagai tokoh lembaga keuangan inspiratif Otoritas Jasa Keuangan (OJK) tahun 2017 dalam kategori Pendukung Pengembangan Asuransi Mikro. 
Penghargaan tersebut diberikan oleh Presiden Joko Widodo pada Pertemuan Awal Tahun Pelaku Industri Jasa Keuangan di tahun 2017 bertempat di Istana Negara (Bakhri, 2017). Sebelumnya Kiai Mahmud sudah mendapatkan penghargaan dari PWNU Jawa Timur atas kiprah dan pengabdiannya dalam Pengembangan Ekonomi Masyarakat (2011) serta dinobatkan sebagai Tokoh Koperasi Jawa Timur (2012). Setelah itu, dia juga mendapatkan Penghargaan "Nahnu Ansorulloh" yang diberikan Pimpinan Pusat (PP) Gerakan Pemuda (GP) Ansor (Bakhri, 2017).

Penghargaan-penghargaan yang didapatkan bukanlah tanpa alasan karena keberhasilannya merintis dan mengembangkan badan usaha sangat jarang dicapai oleh seorang kiai yang perhatian utamanya fokus pada pendidikan dan dakwah. Sebagai lulusan pesantren, Kiai Mahmud tidak tangggung-tanggung menekuni dan mengembangkan badan usaha yang dia dirikan. Banyak anak-anak perusahaan yang lahir dari beberapa badan usaha yang didirikan Kiai mahmud, diantaranya PT Asuransi Syariah Keluarga Indonesia, PT Asyki Sarana Sejahtera (Pialang Asuransi), PT BPPS UMMU (Bank Syariah), PT UGT System Integrator Development (Pembuatan Aplikasi), PT UGT Sidogiri Arsen Telekomunikasi (Persewaan Satelit), PT UGT Sinergi Barokah (Properti), PT Soyugiri Primedika (Rumah Sakit), PT UGTMAS Tour and Travel, PT Angkut Berkah UGT (Sewa Dump Truck), LDP SBC Sidogiri (Diklat dan Pelatihan), dan PT UGT Perkebunan Kelapa Sawit (Anoname, 2018). Dengan banyaknya anak-anak perusahaan yang berdiri, jelas menggambarkan sosok Kiai Mahmud memiliki pengetahuan yang sangat luas dan perhatian yang tinggi terhadap berbagai bidang dalam badan usaha yang didirikan.

Kiai Mahmud juga tidak melepaskan tanggungjawabnya sebagai seorang warga negara yang memiliki kesadaran politik, yaitu memiliki hak memilih dan dipilih. Kiai
Mahmud pernah menjabat sebagai anggota DPD RI pertama pada tahun 2004-2009 dari Jawa Timur. Sebagai seorang enterpreneur dia menjadi Pembina Himpunan pengusaha santri Indonesia (HIPSI). Tidak cukup di situ, sebagai seorang nahdliyyin (warga NU), kiai mahmud menjabat sebagai ketua Rabithah Ma'ahid Islamiyah (RMI) pusat yang merupakan organisasi Badan Otonom Nahdlatul Ulama' (NU) (Jempolindo, 2020). Selain itu, masih banyak jabatan-jabatan lainnya baik di dalam Pesantren Sidogiri maupun di luar sebagai bentuk pengabdiananya kepada bangsa, negara, dan agama.

Beberapa posisi yang dijabat Kiai Mahmud, membuktikan dia benar-benar seorang homo islamicus, yaitu seorang enterpreuner islami yang sukses dalam urusan ekonomi sekaligus mampu memberikan manfaat yang besar nagi kesejahteraan masyarakat. Konsepsi ini tidak hanya ditunjukkan melalui programprogram pemberdayaan yang dilaksanakan oleh badan usaha yang didirikan, tetapi juga ditunjukkan oleh kiprah Kiai Mahmud dalam berbagai organisasi kemasyarakatan. Maka tidak heran, beliau hingga kini dianggap sebagai tauladan di dunia santri dan pesantren khususnya di bidang ekonomi syari'ah.

\section{Konsep Homo Islamicus Monzer Kahf}

Monzer kahf merupakan tokoh ekonomi populer yang dapat diposisikan setara dengan Abdul Mannan dan Nejatullah Siddiqi. Gagasan ekonominya seringkali digolongkan sebagai mazhab mainstream, karena banyak dipengaruhi oleh pendidikan Barat yang ia terima (Khoir, 2010). Pemikiran Monzer Kahf sebenarnya juga didasari oleh Qur'an dan Hadits. Agama menurut Kahf berurusan dengan kepercayaan dan perilaku manusia, sehingga perilaku ekonomi pastinya menjadi salah satu aspek dari agama (Sriwahyuni, 2017). Oleh sebab itu, ekonomi Islam menurutnya adalah cabang ilmu yang mempelajari aksioma, sistem nilai, dan etika Islam. 
Gagasan homo islamicus bagi Kahf sama halnya dengan konsep ibad al rahman yang bertujuan untuk menciptakan masyarakat yang seimbang. Homo islamicus memiliki perilaku rasonal, konsisten dengan tujuan dan kayakinan Allah sebagai Dzat tertinggi dan paling berhak membuat aturan yang akan mengantarkan kesuksesan hidup. Oleh sebab itu, homo islamicus atau enterprenuer yang islami memiliki pilar-pilar tertentu yang sesuai dengan aturan Islam. Menurut Kahf, adapun tiga pilar yang dijadikan pegangan bagi seorang homo islamicus, yaitu (Aravik, 2017):

1. Segala sesuatu adalah mutlak milik Allah dan manusia adalah sebagai khalifah-nya (memiliki hak/bertanggungjawab).

2. Tuhan itu satu dan hanya hukum Allah yang dapat diberlakukan.

3. Kerja adalah kebajikan, sementara kemalasan adalah sifat buruk. Itu sebabnya membutuhkan sikap memperbaiki diri sendiri.

Ketiga pilar tersebut, dapat dipahami bahwa seorang enterpreneur yang islami sejatinya mendasarkan perilaku ekonominya kepada Allah atau keyakinan bahwa segalanya mutlak milik Allah. Tetapi landasan ini tidak serta merta menjadi alasan manusia untuk bermalas-malasan, karena pada pilar ketiga, kemalasan merupakan sifat buruk. Di sinilah ikhtiar berupa usaha yang sungguh-sungguh dalam bidang apapun, memiliki posisi penting sebagai tanggung seorang khalifat al Allahfi al ard (perwakilan Tuhan di muka bumi). Dalam kegiatan ekonomi, ikhtiar itu jelas sangat penting sebagai syarat kesuksesan, meski di akhir Tuhan yang menentukannya.

Kahf mendefinisikan Islam secara ekonometris dengan melihat bahwa kepustakaan ekonomi Islam selama ini dinilainya sebagai gambaran deskriptif mengenai sistem ekonomi Islam. Perilaku ekonomi dalam kepustakaan Islam didominasi oleh 3 prinsip, yakni kepercayaan akan hari akhir, konsep kesuksesan yang dipandang dari segi "taat kepada Allah" dan pelarangan akan penimbunan harta, serta konsep kekayaan sebagai karunia Allah yang harus digunakan untuk kepentingan dan pemenuhan kebutuhan manusia (Corrina da Cahyono, 2019).

Prinsip-prinsip yang dirumuskan Kahf memosisikan homo islamicus pada dasarnya tidak untuk memperoleh untung yang sebesar-besarnya dan menimbun kekayaan semata-mata untuk konsumsi diri sendiri. Kekayaan dalam konsep Kahf memiliki makna fungsional yakni untuk kepentingan pemenuhan kebutuhan hidup, bukan untuk gaya hidup. Selain itu kakayaan juga memiliki makna sosial, karena digunakan untuk membantu kebutuhan hidup orang lain yang disalurkan melalui praktek zakat, infaq, dan shadaqah. Kemudian Batasan-batasan konsumsi terhadap kekayaan ini dirumuskan kembali menjadi empat prinsip diantaranya (Corrina da Cahyono, 2019):

\section{Rasionalitas}

Rasionalitas merupakan perilaku konsusmsi yang berdasarkan moral Islam yakni memakai akal sehat yang diberikan oleh Allah. Penggunaan akal mencakup tiga hal yaitu konsep keberhasilan, skala waktu, dan konsep harta. Keberhasilan ditunjukkan dengan kehalalan barang-barang yang dikonsumsi, skala waktu ditunjukkan dengan mengutamakan ibadah daripada mengonsumsi barang-barang yang tidak bermanfaat, dan semua ditunjukkan dengan keyakinan bahwa semua yang dimiliki hanya titipan dari Allah.

\section{Keseimbangan}

Keseimbangan yang dimaksud adalah konsumsi antara dunia dan akhirat. Perilaku konsumsi dapat disebut seimbang apabila tidak hanya bersifat fungsional, yakni sekedar memenuhi kebutuhan hidup, melainkan juga meluangkan sebagian harta untuk kepentingan sosial, bahkan spiritual dengan berzakat, infaq, shadaqah, kurban atau apapun namanya dengan niatan membersihkan harta, keselamatan akhirat, atau membantu orang lain. 


\section{Barang}

Barang konsumsi dalam pandangan Kahf adalah barang konsumsi sebagaimana dalam Islam yakni halal dan baik. Kata "baik" dalam konteks ini berarti sehat, suci (tidak najis), dan memberi manfaat bagi yang mengosumsi. Kemudian halal adalah barang yang dikonsumsi haruslah bukan barang haram sebagaimana yang telah ditentukan hukumnya dalam Islam baik berdasarkan syariah atau fiqh. Setelah itu barang yang halal dan baik ini juga mesti dimanfaatkan atau digunakan untuk keperluan yang baik dan benar.

\section{Etika}

Perilaku yang terakhir adalah usaha untuk memperoleh barang-barang konsumsi haruslah dengan cara yang halal. Islam melarang dengan tegas cara memperoleh barang dengan riba, mencuri, menipu dan cara-cara licik lainnya. Karena barang halal selain ditentukan oleh hakikatnya juga ditentukan cara mendapatkannya.
Homo islamicus berdasarkan pandangan Kahf sejatinya bukanlah konsep baru yang diciptakan dari ruang kosong. Ia dihadirkan dari nilai-nilai agama Islam yang terkandung dalam nash al-Qur'an dan sunnah, sehingga memiliki karakteristik yang berbeda dengan ekonomi sekuler yang cenderung mengabaikan nilai-nilai agama. Dalam ekonomi sekuler mungkin saja juga berbicara rasionalitas, etika ekonomi, etika konsumsi, tetapi rumusan nilai yang dijadikan pijakan bukan agama atau hukum Tuhan. Ekonomi sekuler menjadikan manusia sebagai pusat segala-galanya atau yang disebut antroposentris, sementara ekonomi Islam cenderung teosentris dengan menjadikan spiritualitas dan eskatologis sebagai tujuan tertinggi.

Secara sederhana perbedaan homo islamicus dengan perilaku ekonomi sekuler atau homo economicus terdapat dalam tabel di bawah ini.

Karakteristik Ekonomi Sekuler dan Islam

\begin{tabular}{|c|c|c|c|}
\hline No & $\begin{array}{l}\text { Variable } \\
\text { Pembeda }\end{array}$ & $\begin{array}{l}\text { Homo economicus } \\
\text { (ekonomi sekuler) }\end{array}$ & Homo islamicus \\
\hline 1 & Rasionlaitas & $\begin{array}{l}\text { Mengukur dalam } \begin{array}{r}\text { kalkulasi } \\
\text { dengan }\end{array} \\
\text { rasionalnya } \\
\text { maksimalisasi kepuasan material } \\
\text { dari utilitas atau keuntungan } \\
\text { individu. }\end{array}$ & $\begin{array}{l}\text { Menerima maksimalisasi } \\
\text { keuntungan individu hanya sebagai } \\
\text { sarana yang untuk mencapai tujuan } \\
\text { penting lainnya seperti perhatian } \\
\text { sosial, moral dan spiritual }\end{array}$ \\
\hline 2 & $\begin{array}{l}\text { Kepentingan } \\
\text { pribadi }\end{array}$ & $\begin{array}{l}\text { Mengukur nilai pada tingkat } \\
\text { dorongan, keinginan, } \\
\text { kesukaan pribadi }\end{array}$ & $\begin{array}{l}\text { Menerima kepentingan pribadi } \\
\text { dalam ekonomi jika dilakukan dalam } \\
\text { norma-norma perilaku yang } \\
\text { ditentukan yakni yang halal dan baik }\end{array}$ \\
\hline 3 & $\begin{array}{l}\text { Etika } \\
\text { Ekonomi }\end{array}$ & $\begin{array}{l}\text { Tidak bergantung pada penilaian } \\
\text { suatu sistem nilai, karena di } \\
\text { bawah madzhab poitif. Nilai / } \\
\text { etika diasumsikan terbentuk di } \\
\text { luar teori ekonomi dan tidak } \\
\text { mampu mempengaruhi } \\
\text { parameter etika tatanan sosial. }\end{array}$ & $\begin{array}{l}\text { Akan selalu berpedoman pada nilai } \\
\text { yang terkandung dalam Al-Qur'an } \\
\text { dan Sunnah dan menolak gagasan } \\
\text { bahwa teori dan kebijakan ekonomi } \\
\text { dapat terjadi dalam iklim } \\
\text { objektivitas positivistik dan } \\
\text { netralitas nilai. }\end{array}$ \\
\hline
\end{tabular}

Homo islamicus dalam konsep selalu didasarkan pada al-Qur'an dan Monzer Kahf merupakan manusia yang dalam praktik enterpreneurnya mengacu pada nilai-nilai dan hukum Islam. Motivasi, perilaku, dan tujuan yang hendak diperoleh
Sunnah yang secara implisit tegas menolak riba, penipuan, dan pencurian. Selain itu, Islam mewajibkan zakat bagi pelaku ekonomi yang sudah mencapai kekayaan 
tertentu untuk dikeluarkan kepada penerima yang secara ketegoris sudah ditetapkan. Tidak cukup di situ kepedulian terhadap sesama, bisa dilakukan secara sukarela melalui infaq dan shadaqah. Ciri-ciri inilah yang menjadi kekhasan Homo economicus atau dalam bahasa yang lain disebut homo islamicus yang berarti enterpreneur yang homo islamicus atau dalam bahasa al-Qur'an disebut ibad al rahman.

\section{Kiai Mahmud Ali Zain sebagai Islamic Man}

Entrepreneurship dalam Islam pada dasarnya bukan hal yang baru, karena agama ini sangat dekat dengan kegiatan ekonomi. Jika ditelusuri lebih jauh Nabi Muhammad saw juga seorang yang bekerja kepada saudagar sukses yang bernama Khadijah yang kelak menjadi istrinya. Islam pada perkembangannya dikenal dan tersebar di Nusantara atas jasa para pedagang dari Arab. Itu sebabnya sampai abad ke-13 banyak ahli yang mengatakan Islam adalah agama kaum pedagang (Darwis, 2017). Kedekatan Islam dengan kegiatan ekonomi ini juga ditunjukkan oleh al-Qur'an dalam mengatur kegiatan jual beli, kerja sama, sewa menyewa dan lain sebagainya yang begitu detail.

Kegiatan ekonomi yang islami secara praktis kembali dihadirkan oleh Kiai Mahmud setelah sekian lama umat Islam dikenal sebagai umat terbelakang, keras, bahkan ada yang menyebut teroris. Islam di tangan Kiai Mahmud terlihat sangat maju dan memiliki potensi bersaing dari segi ekonomi mengalahkan sistem ekonomi sekuler. Dengan berpegang teguh pada prinsip syariah (aturan Islam) yang pasti mengutamakan kehalalan dan menjauhi riba sebagaimana yang digambarkan Kahf dengan etika homo islamicus, Kiai Mahmud melalui Pesantren Sidogiri mendirikan banyak badan usaha yang bergerak di berbagai bidang kegiatan ekonomi, antara lain; Koperasi Pesantren (Kopontren), Koperasi Agro, BMT Maslahah, BMT UGT Sidogiri, dan BPR Syariah. Tiap badan usaha ini memiliki anak usaha meliputi bisnis software, bisnis agro, bisnis kuliner, usaha air mineral, bisnis apartemen mahasiswa, percetakan, dan rumah sakit (Siregar, 2018). Untuk menjaga kehalalanya, BMT UGT Sidogiri dan badan usaha syariah lainnya dalam pembiyaan produk yang ditawarkan menggunakan akad murabahah, di mana harga jualnya terdiri dari harga pokok barang ditambah nilai keuntungan (ribhun) yang disepakati. Pada murabahah, penyerahan barang dilakukan pada saat transaksi, sementara pembayarannya dilakukan secara tunai, tangguh ataupun dicicil (Yuspin, 2007). Akad ini berlaku pada setiap pembiayaan untuk keperluan konsumtif, investasi maupun produktif. Sedangkan riba dalam hubungannya dengan transaksi keuangan menurut Kahf (2006) adalah setiap kenaikan kontrak dalam pinjaman atau hutang karena elemen waktu atau yang kita kenal sekarang sebagai bunga. Akad syariah yang telah dipekenalkan BMT UGT Sidogiri tidak mengakui bunga, karena begitu hutang dibuat, setiap kenaikan hutang adalah bunga dan itu dianggap riba yang dilarang menurut agama Islam. Ini menjadi karakter yang ada dalam setiap badan usaha sayari'ah yang benar-benar menerapkan prinsip Islam seperti di BMT UGT Sidogiri.

$$
\text { Karakteristik lainnya adalah }
$$
moralitas atau pertimbangan etis yang diimplementasikan pada tingkat prinsip maupun pada tingkat peraturan dan regulasi praktis. Menurut Kahf (2004), karakteristik moral ini membuat batas serangkaian tindakan / keputusan / perilaku ekonomi yang dapat diakses. Beberapa ekonom Islam menyebut karakteristik ini sebagai "penyaringan internal dan eksternal moral". Artinya atas pertimbangan moral ini, BMT UGT Sidogiri tidak akan memberikan pinjaman uang dengan untuk tujuan membiayai produksi makanan berbahan daging babi atau produksi minuman keras. Perbedaan lainnya adalah ketika peminjam mampu melunasi pinjaman lebih cepat dari waktu yang ditentukan, dengan akad murabahah, BMT UGT Sidogiri menghapus margin dari sisa hutang. Hal ini berbeda dengan bank sekuler yang tetap membayar 
bunga meski hutangnya dapat dibayar lebih cepat (Bakhri, 2018).

Bank syariah menurut Kahf (2004) tidak berbeda dari lembaga keuangan lainnya dalam hal modalitas hukum, struktur konstitusi, tujuan dan sarana untuk mencapai tujuan tersebut. Perbedaan satu-satunya terletak pada gambaran mereka sebagai Islami. Bank-bank Islam telah memerintahkan diri mereka sendiri untuk menjalankan urusan mereka dalam batas peraturan Islam dan untuk memenuhi tujuan keseluruhannya. Dengan demikian BMT UGT Sidogiri sejatinya sama saja dengan bank sekuler lainnya atau yang disebut bank konvensional. Pebedaannya sangat pada penggunaan aturan-aturan Islam ulai dari akad hingga tujuan pendiriannya. Kehalalan transaksi tanpa riba menjadi prioritas utama dalam bank syariah seperti BMT UGT Sidogiri.

Sebagai sebuah badan usaha yang menggunakan prinsip syari'ah, tentu badan usaha yang didirikan Kiai Mahmud sematamata tidak hanya untuk memperoleh omset sebesar-besarnya. Homo islamicus yang diperkenalkan Kahf, salah satunya menjadikan kerja keras sebagai kebajikan dan kemalasan sebagai sifat buruk, sangat sesuai dengan sosok Kiai Mahmud. Badan usaha yang didirikan sukses meningkatkan aset milyaran hingga trilunan. Pada tahun 2019, tiga badan usaha yang didirikan atau dikelola Kiai Mahmud, menjadi koperasi besar dan tangguh di Indonesia. Kopontren Sidogiri berada pada urutan ke-93, Koperasi BMT Maslahah Sidogiri berada pada urutan ke-14 dan Koperasi BMT UGT Sidogiri berada pada urutan ke-3. Kementrian Koperasi dan UMKM masih mendaftarkan Koperasi BMT UGT Sidogiri sebagai 300 koperasi besar dunia (Bakhri, 2019).

Selain kesuksesan di bidang material, badan usaha tersebut juga menampilkan kesuksesan non material sebagai tujuan tertinggi pendirian bait al mal, yakni untuk membantu kesejahteraan masyarakat sebagaimana konsep homo islamicus Kahf. Atas dasar kesadaran ini, Kiai Mahmud melalui badan usaha yang didirikan membuat seperangkat program untuk membantu masyarakat yang membutuhkan, seperti rutin membayar zakat dan dana sosial.

\section{Zakat}

Perbedaan lainnya antara perbankan sekuler dengan Bait al-Mal Wa al-Tamwil atau yang disingkat BMT, adanya zakat, infaq dan shadaqoh yang rutin dikeluarkan oleh BMT. Ini sesuai dengan prinsip Kahf bahwa harta pada dasarnya hanya milik Allah SWT yang dititipkan kepada manusia untuk kesejahteraan banyak orang. BMT UGT Sidoqiri sebagai badan usaha terbesar yang didirikan Kiai Mahmud rutin mengeluarkan zakat yang disalurkan kepada orang-orang yang berhak sesuai aturan fikih. Penyaluran dana zakat yang dikeluarkan oleh Koperasi BMT UGT Sidogiri diwujudkan dalam bentuk; konsumtif, produktif, beasiswa pendidikan, dan penghargaan living cost atau biaya hidup selama satu tahun kepada para santri yang berprestasi (Bakhri, 2014).

Koperasi BMT UGT Sidogiri dengan omset yang begitu besar hingga di tahun 2017 yang secara total memncapai aset Rp 2,4 triliun dengan sekurang-kurangnya 300 jumlah cabang BMT UGT Sidogiri yang tersebar di sepuluh propinsi (Siregar, 2014). Aset yang begitu besar ini tentu berefek pada besarnya zakat yang dikeluarkan badan usaha ini. Pada tahun 2013 saja, zakat yang dikeluarkan oleh Koperasi BMT UGT Sidogiri sebesar 2,7 milyar dan di tahun 2013 5,2 milyar (Bakhri, 2014). Jumlah ini belum seberapa di banding pada tahun 2017 jumlah zakat yang dikeluarkan mencapai 7,6 milyar dengan aset sebesar 2,4 triliun (Bakhri, 2018). Pada tahun 2020 tentu akan jauh lebih besar lagi jika target 5 triliun berhasil dicapai.

Kewajiban membayar zakat ini merupakan bentuk keseimbangan antara dunia dan akhirat sebagaimana yang dirumuskan Kahf. BMT Sidogiri didirikan oleh Kiai Mahmud dan dikelola oleh anak santri yang sangat memahami prinsipprinsip syari'ah. Dengan kata lain, ketaatan menjalankan kewajiban sebagai bentuk kehidupan yang seimbang antara dunia dan 
akhirat berhasil dijalankan dengan sempurna. Maka tidak heran hingga hari ini Pesantren Sidogiri mendapatkan bagian sebagai penerima zakat sebesar 3,4 milyar pertahun (Siregar, 2018). Hal ini digunakan untuk menekan pembiayaan santri hingga terjangkau bagi masyarakat dengan stratifikasi ekonomi kelas menengah ke bawah sekalipun.

\section{Dana Sosial}

Selain dana zakat, BMT Sidogiri juga menyalurkan dana sosial melalui sisa hasil usaha (SHU) sebesar 15\%. SHU ini menurut Kiai Mahmud selalu mencapai $15 \%$ dan belum pernah di bawahnya (Primus, 2021). Pada RAT tahun buku 2013 yang dilaksanakan tanggal 22 Februari 2014 yang lalu, diputuskan bahwa alokasi dana sosial Koperasi BMT UGT Sidogiri adalah sebesar Rp 9 milyar. Dana sosial tersebut di salurkan ke beberapa penerima yaitu $5 \%$ ke Pesantren Sidogiri, 3\% ke Ikatan Alumni Santri Sidogiri (IASS), $3 \%$ ke Urusan Guru Tugas (UGT) Pesantren Sidogiri dan $4 \%$ dikelola sendiri oleh Koperasi BMT UGT Sidogiri (Bakhri, 2014).

Penggunaan dana sosial yang disalurkan lewat IASS, diperuntukkan untuk mendukung program Qoryah Toyyibah (desa sejahtera) yang diluncurkan sejak tahun 2014 lalu. Tujuan program ini tidak lain untuk membangun desa dengan memberdayakan masyarakat melalui pendidikan, ekonomi, kesehatan, sosial dan lingkungan. Kiai Mahmud sebagai Direktur Qoryah Toyyibah mengatakan, "Kami ingin berpartisipasi dalam membangun Indonesia tanpa harus membebani anggaran pemerintah. Yang ingin kami lakukan adalah memberikan program-program pemberdayaan masyarakat guna mewujudkan Indonesia yang baldatun toyyibatun wa rabbun ghofur (Bakhri, 2014)." Program ini selarah dengan konsep jaminan sosial yang sangat dijunjung tinggi oleh Islam

Jaminan sosial menurut Kahf juga merupakan kegiatan yang sangat ditekankan oleh Islam, karena setiap individu memiliki hak untuk menjalani kehidupan yang layak.
Hal ini juga telah menjadikan pencapaian hak ini oleh individu sebagai tanggung jawab kolektif dari semua anggota masyarakat karena mengartikulasikan sejumlah kerangka kelembagaan untuk solidaritas sosial. Lembaga zakat menjadi salah satu yang paling penting (Kahf, 2015). Sementara kehadiran baitul mal seperti BMT Sidogiri juga sangat tepat karena pemenuhan kehidupan yang layak bagi setiap individu. Dari sini zakat, infaq, shadaqah, dan dana sosial menjadi solusi bagi individu yang belum mencapai kehidupan yang layak. Oleh karena itu, salah satu program Qoryah Toyyibah adalah bedah rumah atau merenovasi rumah yang diangga belum layak huni.

Pada tahun 2014 ketika Qoryah Toyyibah pertama kali berdiri, langsung merenovasi 24 rumah yang dianggap belum memenuhi satandar kelayakan. Masingmasing rumah mendapatkan 25 juta per rumah. Rumah yang direnovasi menurut Kiai Mahmud adalah warga miskin atau para janda yang sudah tidak mampu lagi merenovasi rumahnya, sedangkan rumah yang ditempati sudah tidak layak dihuni (Siregar, 2018). Pada tahun berikutnya program Qoryah Toyyibah memperluas jangkauannya ke desa-desa yang lain. Programnya pun tidak hanya bedah rumah warga, tetapi juga merenovasi lapak atau toko pedagang di sekitar pesantren dengan terlebih dahulu disentralisasi di tempat khusus, sehingga menjadi semacam pusat pedagang kaki lima (Siregar, 2018).

Program-program peningkatan kesejahteraan yang diluncurkan badan usaha yang didirikan Kiai Mahmud nampaknya sudah memenuhi prinsip-prinsip dan tujuan ekonomi Islam yang salah satunya meningkatkan kesejahteraan masyarakat. Kiai Mahmud mengatakan, "dengan melalui berbagai bisnis tersebut dan jaringan yang kami kelola, BMT UGT Sidogiri mampu meningkatkan taraf hidup ekonomi masyarakat." Ungkapan ini menunjukkan sosok Kiai Mahmud sebagai homo islamicus sebagaimana yang diperkenalkan Kahf, yaitu entepreneur yang islami. 


\section{KESIMPULAN}

Kesuksesan badan usaha yang didirikan Kiai Mahmud sangat luar biasa. Berbagai penghargaan telah diterima sebagai bukti pengakuan pemerintah, ormas dan masyarakat terhadap hasil yang telah dicapai dalam bidang ekonomi. Nama BMT UGT Sidogiri, Koperasi Basmalah semakin menjamur dan mendapatkan tempat di hati masyarakat, khusunya masyarakat yang mementingkan kehalalan dalam bertransaksi. Kesuksesan yang dicapai badan usaha ini tentu tidak semata-mata untuk memperoleh keuntungan. Beberapa program yang beorientasi untuk meningkatkan kualitas hidup masyarakat juga telah diluncurkan. Pencapaian ini menjadikan Kiai Mahmud memenuhi kriteria Kahf sebagai homo islamicus.

Keteguhan menerapkan prinsip-prinsip syariah dalam setiap transaksi dan diluncurkannya program-program pemberdayaan, menjadikan Kiai Mahmud telah memenuhi prinsip-prinsip, rasionalitas, keseimbangan, kepemilikan barang, dan etika ekonomi islam. Kemudian dia sepertinya juga memiliki keyakinan bahwa semua milik Allah, keyakinan untuk menerapkan hukum Allah, dan keyakinan untuk berikhtiyar sebagai sebuah kebajikan. Prestasi-prestasi adalah bukti nyata yang semakin memperkuat Sosok Kiai Mahmud layak menjadi tauldan bagi yang lain, khusunya bagi enterprenuer dari kalangan santri.

\section{DAFTAR PUSTAKA}

Anoname. (2018). Koperasi BMT UGT Sidogiri Salah Satu Koperasi Besar Di Indonesia.

https://www.matamatanews.com/kopera si-bmt-ugt-sidogiri-salah-satu-koperasibesar-di-indonesia

Aravik, H. (2017). Sejarah pemikiran ekonomi Islam kontemporer, Depok: Kencana.

Bakhri, M S. (2014). Dana Sosial BMT UGT Sidogiri Rp 9 Miliar. Retrieved from https://www.bmtugtsidogiri.co.id/berita -158-dana-sosial-bmt-ugt-sidogiri-rp-9miliar.html

Bakhri, M S. (2014) Zakat BMT UGT Sidogiri Rp 5 Miliar. Retrieved from https://www.bmtugtsidogiri.co.id/berita -161-zakat-bmt-ugt-sidogiri-rp-5miliar.html

Bakhri, M S. (2017). H. Mahmud Ali Zain Terima Penghargaan dari Presiden. Retrieved from https://bmtugtsidogiri.co.id/berita-454h.-mahmud-ali-zain-terimapenghargaan-dari-presiden.html

Bakhri, M. S. (2018). Ajukan Pembiayaan di BMT UGT Tidak Ribet. Retrieved from https://bmtugtsidogiri.co.id/berita-540ajukan-pembiayaan-di-bmt-ugt-tidakribet.html

Bakhri, M S. (2018). BMT UGT Serahkan Dana Zakat Rp 7,6 Miliar. Retrieved from https://bmtugtsidogiri.co.id/berita533-bmt-ugt-serahkan-dana-zakat-rp7,6-miliar.html

Bakhri, M S. (2019) Cikal Bakal Koperasi Syariah di Sidogiri (1). Retrieved from https://www.bmtugtsidogiri.co.id/berita -621-cikal-bakal-koperasi-syariah-disidogiri-(1).html

Corinna, A. N. dan Cahyono, E. F. (2019) Pola Perilaku Konsumsi Generasi Millenial terhadap Produk Fashion Perspektif Monzer Kahf: Studi Kasus Mahasiswi Universitas Airlangga.Jurnal Ekonomi Syariah Teori dan Terapan, 6 (2), 331-343.

Darwis, M. (2017) Enterpreneurship dalam Perspektif Islam, Meneguhkan Paradigma Peraturan dengan Ekonomi. Iqtishoduna: Jurnal Ekonomi Islam, 6 (1), 1-32.

Fadil, V. (2018) BMT Sidogiri Targetkan Pertumbuhan Asset Rp5 Triliun. Retrieved from https://www.wartaekonomi.co.id/read1 71177/2018-bmt-sidogiri-targetkanpertumbuhan-asset-rp5-triliun.html

Fauzia, I Y. (2014) Prinsip Dasar Ekonomi Islam Perspektif Maqashid al-Syariah. Depok: Kencana. 
Furqani, H. (2011) The Concept Of Human Development In The Notion Of Economic Man: Secular And Islamic Perspective. Media Syariah, 8 (2), 131146.

Imtinan, N. F. (2020) Monzer Kahf: Homo islamicus dan Zakat. Retrieved from https://rahma.id/monzer-kahf-islamicman-dan-zakat/

Jempolindo. (2020) Dima Akhyar Bersama Konglomerat Bersarung Sidogiri. Retrieved from https://jempolindo.id/dima-akhyarbersama-konglomerat-bersarungsidogiri/

Kahf, M. dan Al Yafai, S. (2015) Social Security And Zakāh In Theory And Practice, International Journal of Economics, Management and Accounting, 23 (2), 189-215. Retrieved from

https://journals.iium.edu.my/enmjournal /index.php/enmj/article/view/335

Kahf, M. (2004) Islamic Economics: What Went Wrong. Islamic Development Bank Roundtable on Islamic Economics: Current State of Knowledge and Development of the Discipline, Jeddah May, 26-27. Retrieved from http://www.iefpedia.com/english/wpcontent/uploads/2009/11/Islamic-

Economics-What-Went-Wrong.pdf

Kahf, M. (2006) Innovation And Risk Management In Islamic Finance: Shari'ah Considerations. Paper prepared for the Seventh Harvard International Forum on Islamic Finance, April 1-14. Retrieved from http://monzer.kahf.com/papers/english/I NNOVATION_AND_RISK_MANAG EMENT_IN_ISLAMIC_FINANCE_S HARIAH_CONSIDERATIONS_harvar d_APRIL_06.pdf

Kahf. Monzer (2004) (2004, January). Success factors of Islamic banks. In Brunei Symposium on Islamic Banking and Finance, Brunei, January. Retrieved from http://easymoneyhere.0fees.net/13.pdf
Khoir, Misbahul. (2010) Pemikiran dan Mazhab Ekonomi Islam Kontemporer. Balance: Economic, Business, Management and Accounting Journal $\quad 7 \quad$ (1), 15-26. http://dx.doi.org/10.30651/blc.v7i01

Kholis, Nur. (2015). Kesejahteraan Sosial Di Indonesia Perspektif Ekonomi Islam. Akademika: Jurnal Pemikiran Islam, 20(2), 243-260. Retrieved from https://e-

journal.metrouniv.ac.id/index.php/akad emika/article/view/445

Nurrokhman, Habib Amin. (2021) Pengertian, Tujuan, dan Teori Kewirausahaan (Materi Kuliah). Retrieved from https://bit.ly/3nbn7Gs

Primus, Josephus. (2021) Dua Hal Ini Penting bagi Kemajuan Koperasi di Indonesia. Retrieved from https://ekonomi.kompas.com/read/2018 /02/19/174544426/dua-hal-ini-pentingbagi-kemajuan-koperasi-di-indonesia

Santoso, Sugeng. (2016) Sejarah Ekonomi Islam Kontemporer. An-Nisbah, 3 (1), 59-86.

Siregar, B. (2018) Konglomerat Bersarung Sidogiri. Retrieved from https://www.gatra.com/detail/news/328 110-Konglomerat-Bersarung-Sidogiri

Sriwahyuni, E. (2017) pemikiran ekonomi Islam Monzer Kahf. Al-Intaj: Jurnal Ekonomi dan Perbankan Syariah, 3 (2), 172-186.

Steele, G. R. (2005) Rational Economic Man and His Dog Set Out to Mow a Meadow. The Independent Review, 9 (4), 559562.

https://www.independent.org/publicatio ns/tir/article.asp?id=523

Triningtyas, D. A. (2016) Dasar dasar kewirausahaan, Magetan: Cv. Ae Media Grafika.

Yuspin, W. (2007) Penerapan prinsip syariah dalam pelaksanaan prinsip murabahah. Portal Publikasi Ilmiah UMS, 10 (1). Retrieved from https://publikasiilmiah.ums.ac.id/xmlui/ handle/11617/743 